\title{
THE BIRTH OF SPORTS FROM THE SPIRIT OF AGONAL ECCENTRICITY
}

\section{NACIMIENTO DEL DEPORTE DEL ESPÍRITU DE LA EXCENTRICIDAD AGÓNICA}

\author{
Chaslav D. Koprivitsa \\ Faculty of Political Science, University of Belgrade, Serbia
}

\begin{abstract}
In this paper, we reconstruct the anthropological genesis of the historical assumptions of sport. As a "flawed creature", or as one whose being is determined by the structure of "eccentricity", one has a need for self-overcoming, which manifests itself also as a competition with others, among other things, in physical and playing abilities. Thus another man, in sports as an opponent, represents an "agent" who mediates the processes of selfcognizing and self-fulfillment. For this to be possible, there must be an a priori precondition for competition in humans, which we have named as the conceptual construct of proto-sport.
\end{abstract}

Keywords: SPORT / PHILOSOPHY OF SPORT / ANTHROPOLOGY / ECCENTRICITY / SELF-OVERCOMING / HOMO MAXIMUS

\section{HUMAN'S ROAD TO SPORTING ACTIVITIES}

What is a sport? It is a phenomenon that incarnates a distinct blend of freedom and necessity, and this can be described as a freely self-imposed compulsion to a physical effort aimed at achieving certain playing and/ or competitive goals - likewise freely defined. A play, and then sport, arise from the (mental) self-stimulus of doing what is "not necessary", 1) which is not substantial either for survival, for bodily convenience, or some other need.

Sport is at first, and always, connected with the effort, therefore with something which might evolve

\footnotetext{
1) Suits defines game-playing, which is the basis for many sports, as "a voluntary attempt to overcome unnecessary obstacles" (Suits, 1978, p. 41).
}

\section{EXTRACTO}

En el presente trabajo estamos reconstruyendo la génesis antropológica de las suposiciones históricas de la aparición del deporte. Como un "ser defectuoso", es decir aquel cuyo ser está determinado por la estructura de la "excentricidad", él tiene necesidad de autosuperación que se manifiesta como la competencia con los demás, entre otro también en las habilidades físico-jugadoras. Otro hombre, el adversario en el deporte, representa el "agente" que intermedia en el proceso de autoconocimiento y autorrealización. Para que eso sea posible en el hombre tiene que existir la precondición a priori de competencia, lo que hemos nombrado con el constructo conceptual de protodeporte.

Palabras claves: DEPORTE / FILOSOFÍA DEL DEPORTE / ANTROPOLOGÍA / EXCENTRICIDAD / AUTOSUPERACION / HOMO MAXIMUS

to a kind of physical discomfort, which, in turn, does not exclude the mental satisfaction of overcoming own physical limitations. Sport is a pleasure, ${ }^{2)}$ for which a mentally-induced physical effort is required, associated with the difficulties of physical effort (Suits, 1978). It can thus be defined as vitally unnecessary mental satisfaction conditioned with a sort of conventionally pre-defined physical activities which requires a great deal of endeavour. This un-necessary effort would not be possible if a human is not capable to impose to himself own "commandments" - i.e. to strain to do what he does not need to. This can be

2) Feezell, 2013, p. 15: "The attitudinal pleasures are intentional, and they need not have the 'feel' of sensations." 
described as free stepping-out from the sphere of the necessary and entering into the domain of the un-necessary. This new space arises as such from a constitutive act of freedom, which actually every human, as human, always has already accomplished.

One of the phenomena that is possible due to the human's ability to intentionally step out of the aforementioned regimes of necessity - not only by resisting them, telling them No, but also by creating a new forms of necessity-nonrelated practice, which by their very essence reflect the possibility of being free - it is sport too. If the initial impetus of sporting experience is self-imposing of own physical efforts, then the final horizon of such a mode of experience is self-overcoming, i.e. moving the lines of own bodily limitations and/ or corporeal capabilities in a certain physical and/or playing activity, which transforms sportsman's body in so-called "superbody" [Überkörper] (Caysa, 2003).

The self-overcoming is mediated by reaching for the Other - be it the otherness of other players (co-players and "counter-players", likewise), or otherness of playing - which is other when viewed everyday reality. However, in the end, the basis of this otherness is an attempt to reach a different, more powerful, more desirable, better ... - Me, through self-overcoming. This is happening in all spiritual experiences; precisely, to push towards a different realm, one must be capable to move oneself in its initial stage. The peculiarity of the spiritual act of sporting self-overcoming is that at its peak it implies the overcoming of oneself - and this not just in terms of a certain improvement of own results in playing, but in the way of achieving a moral, even metaphysical victory over oneself. This self-victory is always a precondition for a possible victory over the competitors and for confirmation oneself as a player.

However, self-overcoming should not be understood as an urge of only a certain human sub-type, which has perhaps from the point of view of other, „different” people, a rather strange tendency to prioritize in their lives something which they didn't accomplish or even become, yet. Although in human's dynamically arranged "Being" is always intertwined with something he is not yet, it would be wrong to think that sports, and all the fields of life in which self-overcoming is required, stand for some people's unusual normative preference for the absent, for Not-yet-real. Self-overcoming is anthropologically speaking is operationalization of self-objectification - as an emerging of something which is an expression of myself, in the face of myself, as my result, as a kind the otherness that I produced myself, which, in turn, actually "confirms" that who I am.

Why it is necessary for a human to express himself, which, as we have just seen, also means - to outstrip himself? A human - according to a peculiar, hidden law of Culture - must "beat" himself in order to actually exhibit himself. In a self-victory human realizes (temporarily) unity of his actual self with something previously unavailable to him - serving thus as the previous limit of his powers and his "Being". This unity-in-duality represents the paradoxical formula of the spiritual. Only when a person "beats" himself, when he produces one more victory over himself a small or big- he can realize what he actually was carrying inside himself, without knowing it. Human is, as taught by Sokrates, is always "pregnant” with the More, and something, or somebody (including himself) must affect him to make this „blessed burden" out of himself. The realization of own potential abilities, therefore, involves the shifting of own limits - and not just slightly or somewhat, but to the most achievable "maximum", at the moment. In each person "slumbers" homo maximus (Koprivitsa, $2018)^{3}$. Since we cannot always understand what our ultimate possibilities are - until we (try to) overcome our present limits, so to know - due to insufficiency of purely cognitive means - sometimes means the necessity to physically surpass own hitherto achievable power. From this nonconformity between the theoretical and practical modes of understanding follows that human in this respect could be capable of cognizing only by means of self-surpassing without end. In short, this titanism of "endless" selfovercoming is connected with certain shortcomings in his nature, which makes for human always urgent task: to become aware of his own capabilities and condition ${ }^{4)}$. Therefore, "self-competition” is also a

\footnotetext{
3) That one of basic human traits is longing for maximum is a basic assumption of our book: Homo maximus. Elements of Philosophy of Sports, Belgrade 2018 (in Serbian).

4) But this ethic of maximum, which arises from the aforementioned incongruity, or rather the limitedness of the theoretical mind when it comes to self-cognition, has its reverse side. On the topic we can read by McKibben: "To determine when the 'now is enough' point is reached is no easy task. If you stop too soon, you may miss out on a great opportunity to move forward. And you can set it too far and run against the wall. Is the fifth beer the one that will lead you to a pleasant stun or the one after which you will vomit? (As with beer, so is technology - once drunk and seductive, you can hardly resist the next step)." (Bill McKibben, 2003, p. 123).
} 
matter of self-knowing - in both cases, it is important to determine and to transcend limits, in not quite different ways.

It has been almost from immemorial ancient times anticipated that in human lies this ability. It is to Plato, therefore, attributed the notion that there is no greater victory than the victory over himself, which in ancient Latinity is "translated" as a commandment: te ipsum vincere. Expressed by an indicative formulation of a Slovenian philosopher of sport: "There is something in ourselves that pushes us over the edge. This is a dependence on the progress that we are unable to dismantle." (Hosta, 2014). However, the logic of progress, as a cultural-epochal trait, and self-overcoming, as an anthropological phenomenon, is not quite the same. The latter is the basis for the possibility of the emergence of the first, but the first is certainly not a natural continuation and the ending of an inherently human need. It was rather invented as an attempt of a culture to "fulfill” itself in some waywithin the process of historical self-determination and under the assumptions of secularity.

And the German philosopher Sloterdijk, in addition to the potential controversy between something "eternal" in the human and historical peculiarity of the age of one culture, speaks of "the supra-epochal tendency of modernity towards a de-verticalization of existence" (Sloterdijk, 2009, p. 638) - and this actually means nullification of transcendence, which made possible human unlimited ascent upwards i. e. real verticalization - not of the world picture, which is "deverticalized" indeed, but rather verticalization of basic direction of future moving of existence. Precisely this could signify a human's deeply embedded, "original", not historically learned tendency to make effort to move upward, to surpass oneself. It could, therefore, be said that a necessary condition for the emergence of sports is the human's tendency to self-overcoming, which is at the same time a sort of "inborn" need that arises from the "supra-epochal" conditio humana. As for a sufficient condition - it is "verticalism", which is embodied as an immanent, anthropocentrically conceptualized need of modern human for a constant upward movement, one of the most striking examples of which are sports themselves. The first moment is, conditionally speaking, inherent to the human race, thus representing his "natural" preferment, while the second moment is cultural-historically generated.

The drama of sporting, and, more broadly, every type of existence that aims at overcoming, take place within the space between the present, the existing, the available ... - and the uncertain, the object of stretching out, upwardly. The genesis of this idealtypical lifetime ascent, which is fundamental for this type of ethos, Sloterdijk describes with a successful, "mountaineering" metaphor: "All the ascents start from the base camp of ordinary life." (Sloterdijk, 2009, p. 67). Therefore, unlike the majority - not all of them - other types of stretching out upwards, the surface from which is reflected the "takeoff leg" of human existence towards sport, is everyday reality.

The fact that human tendency to self-overcoming finds its expression in sports, but that, as we have said, is not limited to that area, is maybe in the most explicitly emphasized by the Spanish thinker Ortega y Gasset. According to his opinion, both sports and theoretical thinking, especially in its highest form, philosophy, have a common root - the spirit of unnecessary risk, as a kind of vital "luxury":

[h] owever, the fact is that there are people who need the superfluous. The truth is that [...] there is no such final arrangement, and therefore life [...] since being incomprehensible as utility - is only comprehensible just as a huge sporting phenomenon (Ortega, 2004, p.104) $)^{5}$.

\section{PHENOMENALITY OF ECCENTRICITY}

For a human, his "Being" is given in such a way so that he, unlike an animal, it is not simply what he is, i.e. he does not exist like being simply equal to himself. Rather his "Being" - which means what he is and how he is - is "mediated", i.e. "given" to him through his cognitive self-relatedness, "reflexion". On this basis of this, it is between human and his "Being" inserted the whole area of what is different from him. In this "inserted" area between his "Being" and himself, finally, the Culture itself resides, since it stands for the path of human, when taken in his ontical immediacy, to what himself actually is, which means: transformed and enriched by the creation of his culture. He, therefore, has his "Being" from a distance, in other words - from a priori "thrownness" from the center of what is simply equal to him.

This fundamental feature was called by German philosopher and sociologist Helmuth Plessner "ex-

5) Ortega, G. (2004, p. 106) (our emphasis). 
centricity". The point of this is that human exists by being always "thrown out" from the conceptionalfictional "center" of his own "Being", since Being for him means being-out, being permanently on the way to externality, i.e. otherness of himself. As such, he always finds himself in a peculiar state of being-notyet-(myself-properly); he is constantly on the road towards some final (if not to say "true") him-Self, through his activities, interaction with other people, in general: through the Culture. A human is generally capable of acting because there is a fundamental, insurmountable difference between his "Being" in the "narrow sense" and, conditionally, everything that can justifiably be attributed to him. Precisely within this space of difference, it is opened up the space of his freedom, which, as one of his manifestations has also the sports.

The eccentricity, as the fundamental ontological "dis-placement" of human's Being, has the same starting point with lack of definition of "Being itself", with the rift, so to speak, the inner "emptiness" in his Being, which he is perpetually called upon to fill. Since human, as a species - unlike all animals, has no predefined content of his Being, and therefore is deprived of any definite, solid identity, he, therefore, can is obliged (though immanently) not only to deal with what is necessary to preserve his bare life. Therefore, being actually human means to deal with unnecessary, even more - to broaden that field of freedom, in order to build his identity, which is, for its part, an indefinite task.

From the original emptiness, "unevenness" in the human's Being, as Plessner calls it, can, among other things, also be developed playing and aesthetic phenomena. They all are the fruits of human's through his freedom mediated Being. Precisely freedom makes possible emerging of pathways from the initial, eccentric, with himself "unreconciled" human - to a virtually fulfilled one. To "cure" that the most unpleasant effects of eccentricity do not mean to abolish it as such - which is as a matter of fact not possible. It rather means to find out - through individual life praxis - a personally satisfactory "answer" to the situation of being eternally put in question, so that the initial eccentric structure is being reshaped creatively.

The initial "emptiness" in the human's Being, which stands in close connection with its eccentricity, is an initial ontological "shortcoming", and answer on this is dynamically-dialectically being submitted by the production of surplus - not by mere settling initial challenges. It is with this anthropological shortcoming, which is by Arnold Gehlen called as "burdening", permanently dealt by way of "disburdening". But it turns out quickly that what in the previous situation is being established as a solution for the original burdening, from now on starts to produce a new burdening situation. From human's original imperfection, which makes him a creature of lack [Mängelwesen] - and this anthropological structure is for her side closely intertwined with the eccentricity - arises a series of anthropological phenomena, which are actually manifestations of human permanent misadjustment. Among others, those are play and arts. The game, the sports, the arts, the creation in general, can enrich life only because they can never fully fit into it - namely in human's ordinary, everyday life. After all, all of them are quite different from a mere life.

\section{The essence of human incompleteness}

In what way is human eccentricity relevant for the possibility of active handling with own body, which is a prerequisite for dealing with sports? According to Plesner, "[t]he choice of self-inclusion by rules [...] generally shows human supremacy over the immanence, which would like [...] to isolate him." (Plessner, 1974, pp. 165-6). Human, of course, is not fully superior over immanence - not only in the meaning of the worldly realm but above all as the situational, factual. Still, he is definitely not tied to the immanence, but possess instead a capability of transcending the immanence. This is precisely what is possible thanks to his initial ontological devoid of the state of simple self-unity. Out of this "feature" of not being encapsulated inside of own immanence contrary to the animals' case - comes the human's ability of (mental) taking a stance toward himself, which means both: towards own consciousness- and body-related phenomena.

Plessner rightly sees this dialectical proximity of normatively remote modalities of human's dealing with himself: "As persons, we are our own means." (Plessner, 1974, p. 162). So, personality, which implies being capable to make a choice as a person, and the ability to act instrumentally - even with oneself, i.e. with the parts and moments of own "Being" - those are two sides of the same basic structure.

(Auto)Instrumentality is, furthermore, related to human's expressiveness, and both are connected with his fundamental attitude toward his corporeality: 
But our [expressiveness] is broken since it is exposed to instrumentalization. We are not our own body, although we have it - even though it has also us; we rather in-corporate ourselves. We have to incorporate - but whom exactly? The ones who we are (Plessner, 1974, pp. 162-163).

The ability to take a distance from own world is genuinely mental. And the realm of sports, as a non-serious reality sui generis, is generated as a consequence of the initial mental act of self-retreating from the ("serious") world. In a similar vein, the ability to dispose over own body, i.e. to use for this or that purpose is possible thanks to a fundamental feature of human "Being": failing to fully coincide with himself. This is a consequence of human noncoinciding with its own body, which is converted, or rather convertible, in an active attitude of disposing over it. Thus, a mental act - and in a minimal sense, the disposal over own body is a consequence of a corresponding mental attitude - stands to the ontological fact of human eccentricity as an answer to the question (De Grazia, 2008) ${ }^{6}$.

Plesner, in the aforementioned citation wants to say that something which one expresses and how one expresses oneself must not necessarily be equal to that what one actually is. My self-expression does not have to be equal to myself, precisely as my handling with myself in the instrumental mode does not have to. A human can play roles not only because in certain expressive modalities, just if he wishes, he can be "dishonest", but because his eccentric distance to himself basically allows him to appear in various aspects, under various guises, knowing in advance that in that and that role he is appearing just as such and such - for example, as an artist, worker, public servant, etc. - but not necessarily and always like himself. The human is always referred to the embodiment, which in fact means "acting"

\footnotetext{
6) See also about this: "[h]umans possess a particular ability to retreat from the world, from themselves and, not the least, from their bodies. Accordingly, the being-body [Körper-Sein] has as its counterpole a 'body-having' [Körper-Haben] [...] The bodyhaving is a key difference in relation to animals that do not carry that feature, which is why they remain confined in their bodies. In contrast, a human can take a distance from his body because he is aware of it. His body-awareness is guaranteed to him by the possibility, which is also the ability, to step out from and dealing consequently with him as with the object of his possession. [...] The body-having points to the (mental and physical) abilities that enable us - even compel us - to bring our bodies to an objectifying distance, which again relativizes the envelopness in the body of [our] being-body." (De Grazia, 2008, p. 10).
}

himself: "Human [is] a player [Spieler], as an actor [Schauspieler] of himself" (Plesner, 1976, p. 164). He can play, playing ultimately himself, simply because he is not merely equal to itself, i.e. he is never initially a pure personification of his own identity. On the contrary, he always is only in departing from some actual self-enactment. That is why - in no one my role, and in no one my expressive stepping forward I do not have to appear as a complete I myself. So each of my expressions is in principle shifted, incomplete, in a word - broken.

Plesner counts here with the etymological (though not exclusively) connection between the word body [Körper] and the embodiment [verkörpern]. It is not just about the fact that the human body is the subject of its active behaviour, but his body is the result of his own embodiment, of an effort to build (among other ways also through his body) an image of himself, in order to, through own, in a certain way shaped body - be(come) someone. In a wider sense, human (eccentric) non-coincidence with his "Being" - not only with own body but also with his mind - compels him to try to form his "Being" by his acting so that his work and expression serves as an embodiment of what he actually wants to be. However, the abovementioned brokenness of human expressiveness raises the question of his ability to express himself and to become himself through those expressions.

As part of these considerations, we need to introduce two more aspects from the same Plessner's text, which will help us to understand properly the important conceptual transitions that take place in just mentioned passage. This is the motive of "brokenness" and its connection with the human's ability to express himself: "The dullness in one's own lived body [...] allows us to express ourselves, but in a broken way." "To the dullness in oneself, which is a personality's mark corresponds exteriority to the figures of his own lived corporeality, which enables us to make our body the means of [...] expression." (Plesnner, 1974, pp. 162-163) $)^{7}$. The body as a means

\footnotetext{
7) In connection with this, for the sake of clarification, the following observation should be added: "If being a person [Personsein] is strongly linked to being-self-aware [Selbstbewußt-Sein], then we have to say that at the level of impracticity [Empraktischen - it is a neologism also in German; Ch. K.] we do not have to do with the first mentioned. Contrary to that, if being observed from a of view of corporeal analysis, it must be stated that an individual in the area of impracticity can be completely determined as a person insofar as his power over his actions is proved, thanks to which they could be also attributed to him..." In so far he is, according to Caysa, "a person in a weak sense." (Caysa, 2010, p. 66).
} 
of expression - is it not a sport, too - and not just, for example, a dancing art?

A human can exist as a person or find himself in the process of becoming it - because he is not directly given/present to himself, but in a mediated way, through consciousness. The "magical unity” with oneself, i.e. the pure immediacy, is lost a long time ago - "as soon as acting appropriates the form of mediation, as soon as between human and his work [Werk] an artificial tool [Werkzeug] is inserted." (Cassirer, 1985, p.75). The possibility of dealing with another person has essentially the same root as the possibility of acting towards oneself. This entails the establishment of distance. Within this twofold "rift" - whose one side is not being-melted-with-oneself, and the other one not-dullness-in-the-surrounding - emerges a space for mediation, where, as already said, the symbolic dimension of culture/civilization is settled. Human is - freely, not in pre-arranged manner - co-determined with Otherness, as a dynamic counterpart, or reversed side, of his own identity. Thanks to that, he can carry the "sense" of the otherness within himself, but also to view his environment as a great Otherness of himself.

A human can go beyond the given (in any sense) from the same reason from which he can express himself - because of his ex-centric lack of selfcoincidence. If he were simply identical to himself, he could not even try to outstrip or express himself - as it is for an animal not possible. The true sense of self-overcoming is not just in moving forward "infinitely" possibilities, both personal and generic, but to reach at some point a situation when any further overcoming would not be necessary, since in this ideal, but practically unattainable state, a human would be actually equal to what he should be. The true sense of self-overcoming lies obviously in its (virtual) abolition - by bringing its own "Being" into a state of realization in which his reality would coincide with the ideal. But as with expression issue, this ideal sense of (metaphysics) of self-overcoming has a negative outcome. In all likelihood, a human as such can never achieve a final state of complete selfcoincidence. That is why he has an inexorable longing for distance - not only in the physical but also (even more importantly) in a metaphysical sense. One of the expressions of this tragic craving is the phenomenon of doping in sports, which - besides the influence of the generalization of the modern performance principle, as a social imperative of late capitalism - certainly would have not to be without this a priori anthropological conditionality.

\section{Self-overcoming and self-establishing}

The ontological finding of the eccentricity of a human being, which, in principle, never fully achieves self-discernment, is operationalized as a precondition for the formulation of a typically modern life ethos, which could be summarized in the following way: Being properly means being-more, which leads to: to be-upwards means to be more. Self-overcoming - this is the fundamental form of self-choosing activity of a being faced with the task to find out who he actually is. To establish, to determine who I am - this does not mean only endlessly displaying (to oneself and the others) how much I can more and more move forward, but primarily means to attain a certain life ethos of being-in-self-overcoming, to achieve the goals of own autonomously defined life project. Human's selfovercoming is a way of achieving certain, previously chosen, goals. If, however, self-establishing is reduced to self-overcoming, then the latter could become a self-purpose, instead to stay connected with the ambition to become properly fulfilled - as a person, in general, and as a sportsman, in particular.

It is necessary to point out another feature of human's establishing facts on himself - from the perspective of a culture-historical topos. Sport is an expression of auto-reflexive function, by which a human - through his deeds not in words - finds out what he can produce at the moment. This is a reflection in the literal meaning: re-flexion, which stays in the function of expression. In addition to establishing the "state of affairs" of one's own physical capability, the second point of this reflexive process is the effort to move own physical and playing capabilities whenever and wherever possible. However, those are not two different sides of one phenomenon, but the establishing of limits of something and/ or of someone is inseparable from stepping out beyond them, as limited. A point that somebody is able to reach, as an indicator of his power, and finally of his "Being" - is established by facing his present limits, to (at least) try to overcome them. It turns out that to find out, to measure, on one side, and to move further, to outstrip, on the other side - are mutually inseparably interconnected. Therefore, it is quite hard to keep separate finding out where lies my boundaries/ measure (metron) and shifting them even further, which is typical for the attitude of hybris. 


\section{THE ANTHROPOLOGICAL POINT OF DEPARTURE: PROTO-SPORTS}

Up to now, from the investigation, it has become clear that it is possible for a human to engage with sports, i.e. how he can produce the impulse for that. However, the question arises why he does do it at all? The principle of self-overcoming is only a part though a very important one - of explanations of the genesis of origin of human's entire sporting activity. To be operative, this human's need has to be exemplified in the medium of his physicality. Besides, human spirituality might find his expression in the bodilyphysical plane, but this is not its only manifestation which includes corporeality. Then why does a human transcend himself through sport too? What is it that concerns him that, under certain (favourable) conditions - concerning both the cultural and historical circumstances of the community in which he lives, but also his personal inclinations - could make him practice something like sports?

One of the possible starting points for illuminating this moment was found in Caillois, in his interesting book on the play. He says:

In children, as soon as the personality begins to assert itself, and before the emergence of regulated competition [in their lives - Ch. K.], unusual challenges are frequent, in which the adversaries try to prove their greater endurance (Caillois, 2001, p. 16).

The child then makes all kinds of bets - which, as has been seen, are the elementary forms of agōnwith himself or his friends (Caillois, 2001, pp. 28-29).

The inclination for competition exists even before its institutionalization. Moreover, Caillois emphasizes, rightly, we believe, that playing pre-exists any symbolic order. ${ }^{8)}$ From this brief excerpt, it can be inferred that children, even when they are small, therefore largely independent of the process of cultural learning, tend to contest - with themselves and with others. As the starting point for this inclination, we will assume what we will call an agonal a priori. It does not have a character that could be described as, for example, an "innate idea" or as a genetically "inscribed" predisposition or otherwise. It is a manifestation of a propensity for space-time contest - with oneself, and with others - which arises

\footnotetext{
8) Ibid., p. 29: "[t]he first manifestations of paidia have no name and could not have any, precisely because they are not part of any order, distinctive symbolism."
}

from the human ability to take a reflective attitude, and to evaluate everything that he achieves. The key point here is that being-human - as displayed at an early age - is inseparable from the power to achieve something. On this basis, one can construct an idea of virtue - excellence, not just as a trait of some concrete action or effect, but a constitutive feature of a person. The starting point of both is awareness, which, again, is conditioned by eccentricity.

Agonality is a typical and exclusive human trait, since "[a]gōn is unknown among animals, which have no conception of limits or rules..."(Caillois, 2001, p. 15). We would add: limit is a reflexive term, and rule is an institutional phenomenon, and both, as a cultural effects, can only occur after the emergence of the original impulse for self-overcoming, when the civilized human wants to retrospectively describe and conceptualize what is happening in the "natural human", more precisely with the natural within him.

When animals play with each other, there is absent, by symbolizing enabled, the moment of Asif - concerning serious reality, as in human agonal games. There is no agony in their play, but only a fully "play-full", raw, symbolically unmediated vitality. Only a human, thanks to his eccentricity and consequently reflective attitude, can let "merge" play and competition.

The agonal a priori spontaneously bifurcates into two equiprimordial, mutually inseparable and equiessential forms: the need to contest with the near social environment, which enables him to reach a higher stage of self-accomplishment. Contesting involves a reflexive attitude that takes into account what has been done as a ("mirror") reflection of oneself - in front of oneself. But in addition to reflexivity and appreciation of what has been done, the third inescapable moment of agonal a priori is human's deep-seated need for self-overcoming as a way of self-affirmation - which triggers contesting. Its original form is contesting with oneself in an effort to push further own personal limits and to prove to oneself one's own excellence, or

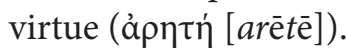

According to the German philosopher of sports Hans-Ulrich Gumbrecht, the basic component of sports is arētē, not agōn (Gumbert, 2005, pp. 46-47). To us, however, the matter seems to be somewhat more complex, since neither the concept of arētè nor the "aretic" practice of any kind is imaginable without self-referential attitude, i.e. without a particular sort of agonality, whose purpose is to "strive" against 
oneself, or more precisely: against one's own, previously detected "weaknesses" - of body and mind. On the other hand, the reality of sports is to compete with others, which actually agōn is; but the ultimate horizon of this is to prove own excellence, that is to affirm and enhance one's personal virtue. So, instead of to put at first place arētē, or agōn, as the German thinker does, it is advisable to adhere to the position they both are inseparable, that they even might dialectically transgress into each another.

Relationship to own identity implies also viewing myself as if I were another (or, conversely, as if someone else was looking at me instead of me) - from a position of reflexive distance. This is why the other I compete with is actually conforming to my reflective otherness with which I observe and evaluate myself and my accomplishments. The other who tries to surpass me - as I do regarding him - is a virtual duplicate of my reflection, in front of which I want to confirm my desire for self-fulfillment. In short, the other, any other, as a competitor, an adversary - but not an enemy, is the incidental embodiment of my projection of my "better" self. Seen from the angle of the sporting unconscious, by wanting to beat him, I actually want to beat myself.

Competing with others is a form of (mutual) noble "taking advantage", in the way that others, in trying to defeat me, in fact "help" me to overcome myself, that is, to come up with something that I until that very moment was not even aware I was capable of. A co-competitor is, thus, an "agent" of my permanent longing for self-improvement, someone who, according to a specific, Hegelian term: "cunning of [sporting] Reason", by his trying to prevail over me - helps me to win myself, i.e. to get (the most) out of myself, more than I could not have accomplished with no competitors around. Since the same goes also for my adversaries, that is for every person who accepts his exposure to the condition of being-challenged, then it must be concluded that, from the existential perspective, the true purpose of sport is not to win in a competition with another, but to make a lasting effort to self-overcoming (Simon, 2010). ${ }^{9)}$

The other, the one with whom I compete, investing his effort, skill and achievement, indirectly shows me (although it is not his intention) how far I can, and the same "service" I provide for him. On the other hand,

\footnotetext{
9) That way, we think, one should read Simon's famous formula about sports as a "mutual quest for excellence" (Simon, 2010, p. 203).
}

even one's physical and spiritual virtue cannot be established acting solely self-referentially - because, after all, there is always a danger of convincing myself of anything that would be pleasing to my sense of complacency, no matter how far could be that far from the truth. That is why the other is here to represent and to embed an impartial measure in the process of never stopping contesting with myself.

Finally, the notion of virtue is something that is a trait of a free, sensed being that can only arise in a community. In the pack or horde, there can be no virtue, even a "sporting” one, related to physical contesting. Virtue is for its part a reflexive term, which is constituted by the cognition of virtue as a virtue. In addition, it counts with the other and his otherness as a person, since only a reflexively impaired person can step into the agonal dimension - not someone who just wants to exert his vital energy.

Agonality is closely linked to the desire for (symbolic) victory. It is not an animal trait, because it does not even have an idea of victory - therefore it cannot even "win", i.e. its actual "victory" (in combat) is never a victory for it, although the „victorious" animal can even be "whispered" afterwards, which is, however, not more than a part of instinct-based behaviour. When, for example, two males compete for primacy in the herd and one of them prevails, he cannot conceptualize this event as his victory. Human, however, is characterized by a desire to win as such, already at a fairly young age. This is because he has a cognitive relation to what he can produce, and this so, that when he actually find out what he at the moment can achieve, he often immediately gets the urge to try to do more, i.e. to move beyond the limits of his capabilities. With this we are, of course, indicating the agonal a priori again.

This agonal craving is particularly heightened by the other striving to be as good as possible in something I also care about. Then the spontaneous tendency to push the limits of own capabilities is not only amplified in quantity but also qualitatively modified - in the desire to surpass the other, i.e. in my desire to prevail over him. Then, at first glance, the initial urge to push the limits of own possibilities is moving in the background, and a thirst for victory comes to the front of human aspirations. However, the qualitative transformation of a self-referential desire to move own possibilities in the desire to win others proves to be illusory, or, at best, partial - because victory, as we have said, only comes from an effort to 
shift own limits. Winning (the other) is actually an effort to persistently "win" myself - by myself. Only the winner over oneself could preserve his hope that "always" will be the winner over others. A victory over the other could perhaps be experienced as more "precious" because the other knows about it - and often someone else: the audience, as a many of "third persons". Still, the anthropological basis for this is composed of the psycho-physical mechanism of self-overcoming, i.e. the human's possibility of "win" himself, which is not only more deeply-seated but also the most difficult and the hardest to be reached.

There is no victory without an explicit relationship toward it, which is present when it comes to competing with oneself, in competition with other(s), and finally, in the third place, in my reflective internalization of the other's relation to me. Thanks to the third moment, the other ceases to be the mere opportunity for my self-contesting but becomes the opponent to whom I develop a relationship of personal rivalry. But he can become my "mirror" just because I already carry that power of self-mirroring.

The "natural" agonality that is displayed in the pursuit of externally unmotivated transcending of own physical capacities we will call the proto-sport. It is our interpretative construct that we want to introduce an explanatory tool for illuminating the condition a priori of the possibility of any human competing, and on that basis, sporting activity. With this protosport, we introduce an originally anthropological, that is, from the human "nature" itself stemming preinstitutional structure, as the generic basis for the possibility of sports and sporting competitions. This is the immediate basis for the possibility of sporting competition in non-ludic sports, while in relation to the ludic ones it also serves as a base, but this time as merged with, to paraphrase Suits, the lusory impulse. As the lusory impulse could also be expressed in nonsporting activities, we will, as a primary case, consider sporting activities that do not involve any play.

The prototype of the competitive sporting activity, which is at the same time the primary manifestation of the proto-sport, as a link between a human being and any sporting action - is running. On the opposite side stands walking, as an elemental, essential for the very life of the (human) organism motoric form, through which, concerning his physical structure, the human capability of moving is exemplified. For example, by snakes, the realization of their capability of moving finds its expression in slithering, by dolphins in swimming, etc. Because it has the status of an elemental form of moving, walking is a factual assumption of other derived types of movement, such as crawling, jumping, climbing, pulling, pushing - unlike, say, nodding [head], waving [hand], and other bodily movements - which do not require the movement of the whole body.

Running is a form of moving, obviously, qualitatively different from walking. It becomes a run when it stops being just fast walking. Walking is a factual assumption for it, not only because one who cannot walk even less can run, but because running is an immediate qualitative modification of walking, while jumping and climbing are, so to speak, elliptical modifications of the general human ability to move, which is primarily manifested by walking. Although walking is a basic motoric form for all types of moving derived from it, running still holds a special place because it is not only an immediate but also a free modification of walking, since one can run not only when forced or when he wants to it gives vent to its vitality - as animals do, but also when it is not externally forced to do it, except internally - by free impulse stemming only from his own will.

However, that is not the full explanation of this question. In order to somewhat complete it, we will resort to the words of a Serbian author - not a scientist, but a writer of fiction: the "urge [to] move as quickly as possible into space" comes from "the power of affirmation of my naked self [...] And as the crown of everything, as the flower itself on the tree of life - [stands] passion of the locomotion." ${ }^{10)}$ This passion is, therefore, one of the supreme manifestations of Eros, by which, through excessive, unnecessary exhilaration, one can joyfully affirm own vital anchorage in life - in one's own, and Life in general.

That running is the primary form of human's free physical contest (with the environment, that is, with himself) is evident by the fact that it is often enough for him to face the ("free") space in order to somehow spontaneously feel himself "called" to cross certain distance as faster as possible. This tacit challenge created by the "interaction" of human nature and the appropriate environment, which "invites" him to behave so, is felt - even above all - by young children, as soon as their walking is stabilized. Of course, no one has to teach or encourage them to do that - they will already do it themselves - regardless of any learning processes or socio-cultural influences. This free

\footnotetext{
${ }^{10)}$ Desnica 1982, p. 415; our emphasis.
} 
longing must already be present in them, and therefore it is phenomenologically important to recognize the originally self-competing moment in human "Being", which we have here called the proto-sport. Still, this is not yet equal to any particular sport, because it can in no way be equated with a spontaneous urge for selfovercoming and competing with oneself, but rather presupposes a planned, institutionalized activity aimed at some sort of socially arranged physical selfcontest.

A variation of that original urge for "contest" with the spatial environment is the challenge of distance - or being-challenged by distance, where it is not important to walk as fast as possible, but to reach as far as possible, which can be modified not only concerning the (horizontal) distance, but also the (vertical) height (mountaineering, parachute jumps) and depth (speleology, diving). And this spontaneous tendency, which is already evident in children as the drive for exploration, is culturally and historically supplemented by human need to light up his world, which in European culture has been expressed in ancient Greek enlightening - not as a kind of particular historical "movement" but as a stable trait of culture. In modernity, this has evolved into an Enlightenment, and typical for this was a sort of commandment that no part of reality - both external and internal - can be left unlit. Therefore, the modern rise of sport does not coincide by chance in time with the rise of the Enlightenment.

The proto-sport of running is not something that all sports, not even non-ludic sports, are derived

\section{REFERENCE}

1. Caillois, R. (2001). Man, play and games. University of Illinois Press, Urbana, Chicago.

2. Cassirer, E. (1985). Symbol, Technik, Sprache. Aufsätze aus den Jahren (1927-1933), Meiner, Hamburg.

3. Caysa, V. (2003). Körperutopien. Eine philosophische Anthropologie des Sports, Campus, Frankfurt/M.

4. Caysa, V. (2010). "Über empraktische Konnerschaft", Zeitschrift für Kulturphilosophie 1: 65-71.

5. Desnica, V. (1982). Proljeća Ivana Galeba [Spring Times of Ivan Galeb], Nolit, Belgrade. from, but what phylogenetically represents free primal activity, which is performed without the need for any purpose that goes beyond it. A frightened person may run when being chased, or for some reason when one of the human types of mobility is connecting with serious reality. More important is the possibility of free "deserialization" of running (disconnecting it from the realm of the serious), because it shows not only another additional line in human behaviour, but represents the connection of the sphere of "nonnecessity" with its nature, or at least with something standing for his "nature". When human for the first time - both as a species and as an individual - start running without any external compulsion, and not because of the mere feeling of the vital forces seeking to exert (which is why animals, for example, might sometimes run for now reason), he thus crosses the threshold of vital necessity and vital "playfulness", opening the space for free physical contest and competition with others.

If sport did not carry this constituent line of rational directing of physical effort, which enables the exertion of physical strength not only to be an end in itself but, under certain circumstances, a means of achieving some lusory goal, it would be a mere vitalistic phenomenon, the bare release of accumulated excess of biological energy, devoid of any (extravital) meaning, let alone purpose. Sport, however, begins where physical exertion is subordinated to some (sporting) goal, where, therefore, the spirit freely, but again according to some freely constructed and accepted rules, directs physical co-efforts.

6. De Grazia, O. (2008). Der Sport "mit anderen Augen". Kritik eines modernen Leitbildes nach der Ausdruckstheorie Helmuth Plessners, Berlin (edoc/hu-berlin.de; accessed: 1. XII . 2017).

7. Feezell, R. (2013). Sport, Philosophy, and Good Lives. University of Nebraska Press, Lincoln, London.

8. Gumbrecht, H-U. (2005). Lob des Sports. Suhrkamp, Frankfurt/M.

9. Hosta, M. (2014) "Ethics of Maximum and Top Sports“. Ivana Zagorac (ed.) O sportu drugačije. Humanistički aspekti sporta [Differently on 
Sports. Humanistic Aspects of Sports], Zagreb 2014, pp. 199-222.

10. Koprivitsa, Ch.D. (2018). Homo maximus. Elements of Philosophy of Sports. [in Serbian]. Ukronija, Belgrade.

11. McKibben, B. (2004). Enough. Staying Human in an Engineered Age. St. Martin's Griffin, New York.

12. Ortega y Gaset, H. (2004). ¿Qué es filosofía?. Espasa Calpe, Madrid.
13. Plessner, H. (1974). "Sport und Spiel“, Diesseits der Utopie. Ausgewählte Beiträge zur Kultursoziologie. Suhrkamp, Düsseldorf.

14. Simon, R. L. (2010). Fair Play: The Ethics of Sport. Westview Press, Boulder.

15. Suits, B. (2019). The Grasshopper. Games, Life, and Utopia. University of Toronto Press, Toronto.

16. Sloterdijk, P. (2009). Du mußt dein Leben ändern. Über Anthropotechnik. Suhrkamp, Franfurt/M.

Submitted: 15.11.2019.

Accepted: 9.12.2019.

Published Online First: 13.12.2019. 


\title{
РОЂЕЊЕ СПОРТА ИЗ ДУХА АГОНАЛНЕ ЕКСЦЕНТРИЧНОСТИ
}

\author{
Часлав Д. Копривица \\ Факултет политичких наука, Универзитет у Београду, Србија
}

\begin{abstract}
Сажетак
У овом раду реконструишемо антрополошку генезу историјских претпоставки појаве спорта. Као „мањкаво створење, односно као онај чије је биће одређено структуром „ексцентричности“, човјек има потребу за самонадилажењем, која се испољава као надметање с другима, поред осталога и у физичко-играчким способностима. Други човјек, у спорту као противник, представља „агента“ који посредује процесе самоспознају и самоостварење. Да би то било могуће, у човјеку мора постојати априорни предуслов надметања, што смо именовали концептуалним конструктом протоспорта.
\end{abstract}

КљУчне речи: СПОРТ / ФИЛОСОФИЈА СПОРТА / АНТРОПОЛОГИЈА / ЕКСЦЕНТРИЧНОСТ / САМОНАДИЛАЖЕҢЕ / HOMOMAXIMUS

\section{ЧОВЈЕКОВ ПУТ КА СПОРТСКИМ ДЈЕЛАТНОСТИМА}

Шта је спорт? То је феномен који оличава особени спој слободе и нужности, и то може се описати као слободно самонаметнута присила на физички напор усмјерен ка остварењу одређених играчких и/или такмичарских циљева - који су такође слободно одређени, односно формулисани. Игра, а затим спорт, настају из (духовног) самоподстрека да се ради оно што се „не мора“,1) што није потребно ни зарад опстанка нити због тјелесне угодности или неке ине потребе или нужде.

Спорт је најприје, али и увијек, повезан с напором, дакле с извјесном физичком неугод= ношћу, што не искључује душевно задовољство због савладавања сопствених тјелесних и физичких ограничења. Спорт јесте задовољство, ${ }^{2)}$ за које је потребан духовно-вољно изазвани физички

\footnotetext{
1) Према Сјутсу, играње игара, што је, у ширем смислу, подлога већине спортова, јесте „добровољни покушај превазилажења непотребних препрека“ (Sjuts, 2019).

2) „Ставска задовољства (attitudinalpleasures) су намјерна и она не морају имати 'осјећај' чулности."
}

напор који је повезан с тјелесном неугодношћу физичког напора (Sjuts, 2019). Он се, дакле, може одредити као животно (не)потребно духовнодушевно задовољство које изискује физички напор. Тај (не)потребни напор не би био могућ да човјек себи не би могао „издавати налог“ - да се потруди око онога што не мора. То се може описати као слободно искорачивање из сфере нужнопотребнога и ступање у сферу не-потребнога. Тај простор уопште настаје из чин(ова) слободе, који је сваки човјек, као човјек, већ био извршио.

Један од феномена који је могућ захваљујући човјековој способности интенционалног искорачивања из поменутих режима нужности - не само тако што ће им се одупирати, рећи им не, већ и на тај начин што ће стваралачки обликовати нове видове, с нужностима неповезане праксе, које самим својим бићем оличавају могућност бивања слободним - јесте и спорт. Ако је иницијални покретач спортског искуства наметање себи напора, тада крајњи смисаони хоризонт таквог искуственог режима представља самона- 
дилажење, тј. помијерање граница своје тјелесне ограничености у извјесној физичкој и/или играчкој дјелатности - преображајем својега тијела у „надтијело“з) [Überkörper] - што се све скупа иницира посредством властитог духа (Caysa, 2003).

Самонадилажење посредовано је посезањем ка другом - било да је та другост других играча (саиграча или противиграча), или другост саме игре. Но, у крајњем, основа те другости јесте покушај да се надмашивањем себе досегне другачије, моћније, боље... - ја. То се дешава у свим духовним искуствима, јер да би се иступило ка другом, односно другачијем, мора се изаћи из себе. Особеност духовног чина спортског самонадилажења јесте у томе што оно на својем врхунцу подразумијева надилажење себе самога - и то не тек у неком резултатском смислу извјесног благог побољшавања својих резултата, већ на начин моралне, чак метафизичке побједе над самим собом. Та побједа услов је побједе над такмацима и потврђивање себе као играча.

Самонадилажење, међутим,не треба схватити само као порив једног соја људи, који имају, тобоже чудновату склоност да предност увијек дају ономе што још није, односно што нијесу постигли. Иако се у човјековом динамичком бићу увијек преплићу оно што (он) још није и оно што (он) јесте, погрешно би било мислити да спорт, и сва поља живота у којима се изискује самонадилажење- представљају нормативно хипостазирање одсутнога, још не-стварнога пред стварним. Самонадилажење је у функцији самоопредмећивања - као појављивања онога што је израз мене самога насупрот мени, као мој резултат, као нека врста другости која је произашла из мене, која ми повратно „потврђује“ ко сам ја.

Зашто је, међутим, неопходно да се човјек надмаши да би се испољио? Човјек мора да побиједи себе да би заправо себе испољио. У самопобједи човјек остварује (привремено) јединство актуалног себе с оним што му је дотад било недоступно, служећи на тај начин као ранија граница његових моћи и његовог бића. То јединство-и-двојство представља парадоксалну формулу духа. Тек када човјек себе „побиједи“,

\footnotetext{
3) Caysa (2003), стр. 73: „Замисао надтијела [Überkörper] треба разумјети као грађевину, као споменик наше побједе над собом самим и као споменик наше слободе спрам себе.“
}

када оствари још једну - малу или велику побједу над собом, тачније над собом какав је себи до тог тренутка самопобједе био познат, односно „дат“, каквом га је „видјела“ његова ауторефлексија - он може да схвати шта је заправо већ некако носио у себи, а да то није знао. Човјек је, као што подучава Сократ, увијек „бременит“ оним Више, па нешто, или неко (укључујући и њега самога) мора да га побуди да би подстакло да изњедри ово „благословено бреме“. Спознаја својих потенцијалних способности, дакле, подразумијева помијерање својих граница не тек помало или донекле, већ, концептуално посматрано, до „максимума“. У сваком човјеку „дријема“ homomaximus (Копривица, 2018)" Пошто не можемо схватити које су нам крајње могућности док не (покушамо да) преступимо преко својих крајњих граница, то значи да спознати своје физичке моћи значи побиједити себе. Из ове, да тако кажемо, неусаглашености теоријско спознајног и практичко спознајног режима слиједи да се човјеку овом погледуспознаје само на путу самонадилажења без краја. Укратко, титанизам „бескрајнога" самонадилажења скопчан је са извјесним недостатком, што човјеку увијек чини хитним задатак постајање свјесним својих способности и свог стања (Hosta, 2014, стр. 210). Стога, „самонадметање“ је увијек и ствар самосазнавања - у оба случаја важно је одредити и прекорачити границе, и то на сасвим различите начине.

Од давнина се наслућивало да у човјеку лежи ова способност, да чак у њој лежи важна могућност, чак оно што је препознатљиво људско. Платону се, тако, приписује схватање да нема веће побједе од побједе над собом самим, што је још у древном латинитету „дублирано“ као заповијест: te ipsum vincere- побиједи себе самога. Изречено индикативном формулацијом једног савременог словеначког философа спорта: „Нешто је у нама самима што нас гура преко руба. Ријеч је о овисности о напретку коју нисмо у стању раскринкати“. Логика напретка, као културноепохалног, и надилажења, као антрополошкоонтичког феномена, нијесу исте ствари. Потоње је подлога могућности појаве првога, али то прво свакако није природни наставак и завршетак

\footnotetext{
4) То да је једна од главних људских црта тежња за максимумом, основна је претпоставка књиге: Homomaximus. Елементи философије спорта, Београд, 2018.
} 
инхерентно људске потребе, већ нешто што је изумљено као настојање једне културе да у процесу повијеснога самоналажења - и то под претпоставкама секуларности - на неки начин „оствари“ себе.

И њемачки философ Слотердајк, надовезујући ce на потенцијалну контроверзију односа „вјечно“-антрополошкога и културноповијесне специфичности једнога доба, говори о „надепохалној усмјерености модѐрне ка девертикализовању егзистенције“ (Sloterdijk, 2009, стр. 638)што заправо значи поништење трансценденције, што је омогућило неограничени успон навише, тј. право вертикализовање - не слике свијета, која је заиста девертикализована, већ основног смјера будућег кретања егзистенције. Управо то би могло да означи дубоко усађено, притом изворно, не научено, човјеково настојање да се креће нагоре, да се надмашује. Могло би се, стога, рећи да је потребан услов за настанак спорта - човјекова склоност ка самонадилажењу, која је уједно и исконска потреба која проистиче из „надепохалне“ condition humana-е; довољан услов: „вертикализам“, који се оличава у иманентној, антропоцентрично постављеној, потреби модерног човјека за сталним узлетом навише, чији је један од најупечаљтивијих примјера управо спорт. Први момент, својствен, условно казано, човјеку као врсти, представља, такорећи, његову „природну“ склоност, док је други момент културноповијесно настао, и не спада у домен природне условљености, већ у себи носи црту културне конструисаности и утолико контингентности.

Драма спортске, и, шире, сваке ка надмашивању усмјерене егзистенције одиграва се између садашњега, постојећега, расположивога... - и онога неизвјеснога, чему се тежи, навише. Генезу животног пута успона, као темељног типа етоса, Слотердајк описује једном успјелом, „планинарском“ метафором: „Сви успони започињу у базном логору уобичајеног живота“ (Sloterdijk, 2009, стр. 67). Но за разлику од већине, не свих - осталих типова сезања навише, одскочиште, површ с кога се одбацује „одразна нога“ човјекове егзистенције ка спорту, јесте свакодневница, дакле „нормална“, озбиљна стварност.

То да човјекова склоност ка самонадилажењу налази израза у спорту, али да, како рекосмо, није ограничена само на то подручје, можда најодлучније наглашава велики шпански мислилац Ортега и Гасет [José Ortega у Gasset]. Према његовом схватању, и спорт и проблемско теоријско мишљење, чак у својем највишем виду, философији, имају заједнички коријен - из духа непотребног ризика, односно својеврсног „луксуза“:

[м]еђутим, чињеница је да има људи којима је потребно оно што је излишно. [...] Истина је та [...] да не постоји такво коначно устројство те да је зато живот,[...] будући заправо несхватљив као утилитарност, објашњив тек као огроман спортски феномен (Ortega, 2004) ${ }^{5}$.

\section{ФЕНОМЕНАЛНОСТ ЕКСЦЕНТРИЧНОСТИ}

Човјеку је његово биће дато тако што он, за разлику од животиње, није напросто то што јесте, није без даљњега и само раван самоме себи, већ му је биће, дакле то шта јесте и како бива - испосредовано, тј. „даје“ му се путем самоодношења. На основу тога се између њега и његовог бића „умеће“ читаво подручје онога што је од њега, макар непосредно посматрано, различито. У том уметнутом подручју између његовог бића и њега самога пребива, коначно, и сама култура, будући да она јесте пут човјека, узетог у његовој некој тренутној непосредности, ка себи самоме, али сада преиначеног и оплемењеног том културом. Он, дакле, своје биће „има“ из самоудаљености, другачије казано - из априорне избачености из средишта онога што је њему напросто равно.

Ту темељну црту, њемачки философ и социолог Плеснер [Helmuth Plessner] назвао je „ексцентричношћу“. Смисао тога је да човјек бива тако што је свагда већ „избачен“ из концептуалнофиктивног тежишта властитог бића, тако што избива - будући стално на путу ка спољашњости, односно својој другачијости.. Као такав, он је увијек у стању некаквог још-не(-ја-са̂м), стално се налази тек на путу ка неком крајњем (да не кажемо и „истинском“) себи, и то преко нечега другачијега од стања својег затеченог самства (тј. преко својих дјелатности, других људи, уопште

5) Ortega, G. (2004, стр. 106) (подвлачење аутора). 
- културе). Човјек, уопштено, може да дјелује зато што постоји разлика између његовог бића у „ужем смислу“ и, условно казано, свега онога што му се може приписати, а у тој разлици, или јазу, отвара се уопште простор његове слободе, које за једну од својих манифестација има и спорт.

Ексцентричност, као темељна онтолошка измјештеност људског бића, има исто исходиште са човјековом неодређеношћу, са јазом, да тако кажемо, унутрашњом „празнином“ у његовом бићу, коју је он вазда позван да попуни. Пошто човјек, као врста, нема унапријед установљено биће, па тиме ни зајамчен, чврсти идентитет, он стога не само што може него и треба да се бави и оним што не представља само дјелатност на очувању голог живота. Стога бити заправо људски значи имати посла са не-нужним, још вишим: ширити поље слободе зарад изградње свог идентитета, што је, међутим, бесконачан задатак.

Из изворне празнине, „неравнине“ у човјековом бићу, могу, поред осталога, настати и играчко-естетски феномени. Они су плод човјекове слободе, што представља један могући пут од почетног, ексцентричног, са самим собом неизмиренога човјека - ка испуњеном човјеку. Залијечити ексцентричност не значи укинути је - што није ни могуће - већ значи наћи посредан, индивидуално задовољавајући одговор, којим ce почетна констелација ексцентричности стваралачки преиначује.

Почетна „празнина“ у човјековом бићу, која стоји у тијесној вези с његовом ексцентричношћу, представља иницијални онтолошки „мањак“, на који се, динамичко-дијалектички, одговара производњом вишка - не и поравнањем. Мањакоптерећење производи растерећење, који се убрзо успоставља као узрок новога оптерећења. Из човјекове изворне неприлагођености, које га чини мањкавим створењем (Mängelwesen Геленова [Arnold Gehlen] антрополошка теза, као и она о оптерећењу), што је друго име за његову ексцентричност, настаје низ антрополошких феномена који су заправо манифестације трајне неприлагодљивости, а то су (артифицијелна) игра и умјетност. Игра, спорт, умјетност, уопште стварање, могу да оплемењују живот само зато што се никада не могу у потпуности уклопити у њега, јер су и увијек и након свега ипак, суштински другачији од њега, наиме од пукога живота.

\section{Биће недовршености}

На који начин је човјекова ексцентричност релевантна за могућност активног опхођења са својим тијелом, што је предуслов бављења спортом. Према Плеснеру, „[и]збор самоукључења помоћу правила [...] уопштено показује човјекову надмоћ над иманенцијом, која би хтјела [...] да га изолује“ (Plessner, 1974, стр. 165-6). Човјек, наравно, није надмоћан над иманенцијом -не само у значењу овостранога, већ прије свега ситуативнога, фактичкога - али свакако није за њу неопозиво везан, већ има могућност њенога надилажења. Управо то је могуће захваљујћи његовој иницијалној онтолошкој лишености стања простог самојединства. Из те „црте“ незаробљености у властитој иманенцији - а противпримјер томе су животиње - произлази човјекова могућност (духовног) одношења према себи, тј. и према својој свијести и према својем тијелу.

Плеснер исправно примјећује ову дијалектичку близину нормативно удаљених модалитета самоодношења: „Као особе, ми јесмо властита средства (Plessner, 1974, стр 162). Дакле, личносност, тј. бивање кадрим да се бива као једна особа, и могућност поступања у инструменталном модалитету - чак и са самим собом, тј. са дијеловима и моментима сопственога бића - два су лица истога темељнога склопа.

(Ауто)Инструменталност је, надаље, у вези са човјековом експресивношћу, а обоје су повезани с човјековим темељним држањем према својој тјелесности:

Но наша [експресивност] је преломљена, будући да је изложена инструментализовању. Ми нијесмо своје тијело, иако га имамо - иако и оно нас има, већ ми себе отјеловљујемо. Ми морамо отјеловљивати - али кога? Оне који јесмо (Plesnner, 1974, стр. 162-163).

Способност узимања одстојања од својега свијета јесте духовна способност. И спорт, као неозбиљна (што не значи неозбиљна!) стварност sui generis, настаје као посљедица иницијалног духовног чина човјековог одаљења од (озбиљног) свијета. Исто тако, и могућност располагања својим тијелом, тј. способност његовога (пре) усмјеравања за ову или ону сврху, у формалном смислу могућа је захваљујући његовој онтолошкој несамоподударности. То има за посљедицу човјеково неподударање са својим тијелом, која 
се претвара, или је прије претвориво, у активно располагања њиме. Дакле, духовни чин - а у минималном смислу и располагање својим тијелом јесте духовни чин, односно духовни став - према онтолошкој чињеници човјекове ексцентричности односи се као одговор према питању (DeGrazia, 2008). ${ }^{6}$

Плеснер у малопређашњем наводу жели рећи да оно што изразим и како се изразим не морам бити испрва и нужно баш ја сам. Мој израз не мора бити раван мени као ни моја самоинструментализација. Човјек може играти улоге не само зато што у одређеним изражајним модалитетима, ако пожели, може бити и „неискрен“ већ стога што му ексцентрична дистанција спрам себе самога начелно омогућује појављивање у различитим аспектима, под разним видовима, тј. тако што унапријед зна да се у тој и тој улози појављује као тај и тај - нпр. као умјетник, „мануелац“, „функционер“ итд - али нужно и увијек као он сам. Човјек је вазда упућен на отјеловљивање, што заправо значи „глумљење“ себе самога: „Човјек [јесте] играч [Spieler], као глумац [Schauspieler] себе самога?" Он може да се игра, у крајњем да игра и себе, напросто зато што није раван себи, што никада најприје није оличење чистога идентитета, већ увијек јесте само из неке актуалне изведбе својег односа спрам себе самога. Баш због тога, ни у једној својој улози, ни у једном својем изражајном иступу, ја не морам да са појавим као цјеловити ја-сам. Сваки мој израз начелно је помјерен, нецјеловит, ријечју преломљен.

Плеснер рачуна на етимолошку (али не само етимолошку) везу између ријечи тијело (Körper) и отјеловити (verkörpern). Ту није ријеч само о томе да је човјеково тијело предмет његовог активног одношења, већ је његово тијело резултат

6) О томе видјети и овдје: „[љ]уди посједују нарочиту способност дистанцирања од свијета, од себе и, не напослијетку, и од сопственог тијела. Сходно томе, тјелесност/ тјело-бивање [Körper-Sein] као противпол има 'тјело-имање' [Körper-Haben]... Тјело-имање представља кључну разлику у односу на животиње, које то немају, због чега остају заточене у своја тијела. Насупрот њима, човјек може узети одстојање од својег тијела зато што је њега свјестан. Свијест о својем тијелу јамчи му могућност, која је уједно и способност, иступања из њега опхођења с њиме као са објектом својега посједовања. [...] [т]јело-имање упућује на (духовне и тјелесне) способности које нам омогућују - чак нас принуђују - на довођење својега тијела на објективишућу удаљеност, што, опет, релативизује увијеност у тијело [нашег] тјело-бивања.“ (DeGrazia, O., 2008, стр. 10). његовог властитог отјеловљења, настојања да се, поред осталога и помоћу својега тијела, изгради једна слика о себи, да се, помоћу на одређени начин обликованог и изображеног тијела буде неко. У ширем смислу, (ексцентрично) неподударање нашег бића не само са својим тијелом него и са својим духом човјека нагони да своје биће обликује властитим чињењем, да његова дјелатност, рад и израз, којим се онда, буду оличења (или о-тјеловљење) онога што он заправо жели бити. Међутим, управо поменута преломљеност човјекове изражајности отвара питање његове могућности да изрази себе самога.

У склопу ових разматрања треба увести још два момента из истога текста, који ће нам помоћи да боље разумијемо важне концептуалне прелазе у управо датоме одломку. Ријеч је о мотиву „преломљености“, те о њеној вези са човјековом способношћу изражавања: „Утонулост у сопствену плот [...] омогућује нам да се изразимо, али преломљено.“ „Утонулости у себе саме, што је ознака личносности (Personalität), ${ }^{7}$ одговара испољивост (Exteriorität) у односу на своје плотне (leibhaften) фигуре, што нам омогућује да своје тијело учинимо средством [...] израза.“ (Plesnner, 1974, стр. 162-163). Тијело као средство израза - није ли то и спорт, а не само, рецимо, плесна умјетност?

Човјек може бивати, односно постајати особа зато што себи није непосредно дат/присутан, већ путем свијести. „Магијско јединство“ себе са собом, чиста непосредност, изгубљено је „чим чињење пређе у форму посредности, чим се између човјека и његовог дјела (Werk) уметне оруђе (Werkzeug)“ (Cassirer, 1985, стр 75). Могућност опхођења са другим, суштински има исти коријен као и могућност одношења према себи. То за собом повлачи успостављање даљине, посредности. У тој дволикој „пукотини“ - чије је једно лице несливеност са собом, а друга неутонулост у

7) У вези с овим, ради разјашњења, треба додати сљедеће запажање: „Ако се личносност [Personsein] у јаком смислу везује за самосвијест-ност [Selbstbewußt-Sein], тада морамо рећи да у равни упраксовљености [Empraktischen - о овом појму видјети и одјељцима 15.2 и 15.3] још немамо посла са првопоменутом. Насупрот томе, посматрано са тјелесноаналитичког становишта, ваља устврдити да се појединац у подручју упраксовљености у потпуности може одредити као особа [Person] утолико што то доказује његова моћ над својим дјеловањем, захваљујући чему му се оно може приписати...“ Утолико је он, према Кајси, „особа у слабом смислу“(Caysa, V., 2010, стр. 66). 
околно̄ - појављује се простор за посредовање, у којем се, како већ рекосмо, насељава симболичка димензија културно-цивилизацијскога̄. Човјек је слободно, не предетерминистички, саодређен другошћу, као динамичким антагонистом, или пак наличјем сопственог идентитета. Благодарећи томе он другост носи у себи, а своје окружење препознаје као једну велику другост.

Човјек може да се надилази из истога разлога из којега може да се изражава - због своје ексцентричне самонеподударности. Да јесте напросто раван себи самоме, човјек не би могао ни да покуша да се надмаши, односно да се изрази - као што то животињи apriori није могуће. Прави смисао самонадаилажења није да се тек помијерају у „бескрај“ своје могућности, односно могућности људскога рода, већ да се у неком тренутку дође до стања када никакво надилажење не би било ни могуће нитипотребно, будућида биутом идеалном стању човјек актуално био раван ономе што треба бити. Истински смисао самонадилажења лежи очевидно у његовом укидању - довођењем властитог бића у стања остварености у којем би коинцидирали реално и идеално. Но као и код изражавања, овај идеални смисао (метафизике) самонадилажења има негативни исход. По свој прилици, човјек, као човјек, никада не може да постигне коначни самонадилазак који би га довео до потпуне самоподударности. Зато му преостаје неискорјењива чежња за даљином - не само у физички просторном него и, што је важније, у начелном, метафизичком смислу. Израз те трагичне жудње јесте и феномен допинга у спорту, којега, осим социоепохалног утицаја антрополошке генерализације модерног начела учинка, као социјалног императива позног капитализма, свакако не би било и без ове априорне антрополошке условљености.

\section{САМОНАДИЛАЖЕЊЕ И САМОУСТАНОВЉАВАҢЕ}

Онтолошки налаз о ексцентричности човјековог бића, које начелно никада актуално не постиже самоподударност, операционализује се као одскочна даска за формулацију типично модерног животно практичког етоса, који би се могао сажети и на сљедећи начин: Бити заправо, значи бити-више. А би(ва)ти-(на)више значи вишебити. Самонадилажење - то је темељни облик самобирања створења суоченог са задатаком самоустановљавња. Установити себе, одредити се, то не значи само непрекидно показивати (себи и другима) колико се све још/даље може, него прије свега значи обликовати одређени животни етос свагдашњега бивања-у-самонадилажењу, ради постизања циљева својег животног пројекта.

Човјеково самонадилажење форма је постизања одређених, претходно изабраних, садржинских циљева. Ако се, међутим, самоустановљавање сведе на самонадилажење, тада формално-медијални момент почиње да у потпуности запрема животну праксу, а од садржинског момента - што би требало бити исход самоустановљавања - готово да не остаје ништа. Зато животни став не смије бити сведен само на етос самонадилажења. Ако бисмо самонадилажење посматрали и из спортско практичне и животно практичке перспективе, тада стремљење вишем добија своје пуно оправдање и смисао када није само себи сврха, већ када је у дослуху са настојањем да се буде лично испуњен - и као спортиста и као особа.

Потребно је указати и на још једну особеност установљавања чињеничнога стања - и то из угла једног повијесно културног топоса. Спорт је израз и мјера човјекове ауто-рефлексивне функције путем које дјелом не ријечју, установљава колико може. Ријеч је о рефлексији у дословном значењу: одбијање, као одражавање, што је у функцији и изражавања. Поред установљавања „чињеничног стања" властите физичке спремности, други момент овог рефлексивног процеса јесте настојање да се сопствене физичке и играчке могућности помијерају - кадгод је и колико год је то могуће. То, међутим, нијесу двије различите стране или „ставке“ једнога феномена, већ је установљавање, као утврђивање граница нечега и/или некога, неодвојиво од њиховога преступања. То докле нешто/неко иде, докле се простире нечија моћ, способност, најпослије биће - установљава се суочавањем са границом, као (макар) покушајем да се она прекорачи. Показује се да су установити, одмјерити, на једној страни, и помаћи даље, надвисити, на другој страни, међусобно неразлучиво повезани. Наћи мјеру, као оптимално „средњим“, на једној страни, и тежити за вишим, бољим - прекомјерним - 
на другој, двије су стране истога, и то не стога што би нас на такав закључак упућивала нека философска игра појмовима, већ зато што човјек, у настојању да нешто постигне, односно да себе, у неком погледу и сегменту, оствари, не може одвојити једно од другога. Тако се показује да су двије судбинске ријечи грчке културе, као родног мјеста европске културе уопште - metron (мјера) и hybris (дрскост) иако на први поглед, по идеалном смислу, усмјерене једна против друге, реално не само двије стране истога него и да чак свој примјерен израз налазе и у спорту. Спорт је, дакле, и израз духа мјере и сталног настојања да се из њега искорачи.

\section{АНТРОПОЛОШКО ИСХОДИШТЕ СПОРТА: ПРОТОСПОРТ}

Из досадашњег тока истраживања постало је јасно како је могуће да се човјек бави спортом, тј. како се рађа тај (само)подстрек. Поставља се, међутим, питањезаштосечовјекњимбави? Начело самонадилажења представља само дио, истина важан, објашњења генезе родног исходишта човјекове свеколике спортске дјелатности. Но човјекова потреба за самонадилажењем не мора бити егземплификована на физичком пољу. Иначе, човјекова духовност налази израза у тјелесно-физичкој равни, али она није једина пројава која укључује тјелесност. Зашто онда човјек себе надилази и путем спорта? Шта је то у њему што га, под одређеним (повољним) условима - који се тиче и културно повијесних прилика заједнице у којој живи, и његових личних животних околности - могу навести да се бави нечим попут спорта?

Једно од могућих полазишта за освјетљавање овога момента нашли смо код Кајое, у његовом занимљивом и успјелом спису о игри. Он каже:

Код дјеце, чим почне да им се помаља личносност, а прије појаве уређених такмичења [у њиховим животима - Ч. К.] чести су необични изазови у којима противници покушавају да докажу већу издржљивост (Caillois, 2001, стр. 16).

Дијете тада улази у најразличитије врсте опклада, које су [...] елементарне форме агона - са собом и са својим пријатељима. Уопштено, [то су] прве пројаве дјетињарије [лаเઈía; дословно: игра] ...( Caillois, 2001, стр. 28-29).

Порив за надметање постоји и прије својег институционализовања. Кајоа чак наглашава, исправно, вјерујемо, да играње претходни било каквом симболичком поретку. ${ }^{8)}$ Из овога краткога извода може се закључити да дјеца, чак и када су мала, дакле махом независно од процеса културног учења, имају склоност ка огледању - и са собом и са другима. Као исходиште ове склоности претпоставићемо оно што ћемо назвати агоналним априоријем. Оно нема карактер који би се могао описати као, на примјер, „урођена идеја“ или као генетски „уписана“ предиспозиција или како већ иначе. Ријеч је о испољавању склоности ка просторновременском одмјеравању - са собом, односно са другима - која произлази из човјекове могућности рефлексивног (само)одношења, заузимања става према ономе што чини, те процјене онога што постиже. Притом је кључно то да је битичовјек - што се показује већ у раном узрасту неодвојиво од моћи-нешто-постизати. На основу тога човјек уопште може изградити представу о врлини - изврсности не само као одлици неке конкретне радње или учинка, већ конститутивној црти бића људске особе. Исходиште и једнога и другога јесте свјесност, која је, опет, условљена ексцентричношћу.

Агоналност је типично и искључиво људско својство, будући да је „[а]гон непознат међу животињама, које немају предоџбу о границама или правилима...“ (Caillois, 2001, стр. 15). Додали бисмо, граница је рефлексивни појам, а правило је институционални феномен, а обоје, као културални учинци, могу да се појаве тек послије изворног порива за самонадилажењем, када човјек цивилизације жели да ретроспективно опише и појми оно што се дешава у „природном човјеку“, тачније с оним природним у човјеку.

Када се животиње међусобно играју, ту нема, симболизацијом омогућенога, момента као-да, (у односу на озбиљну стварност) као у човјековим агоналним играма.У њиховој игри нема никаквога агона, већ само потпуно раз-игранога испољавања сирове, симболички непрерађене животности. Само човјек, захваљујући својој ексцен=

\footnotetext{
8) Ibid., p. 29: “[п]рве пројаве paidia-е немају име, нити би га уопште могле имати, управо зато што не припадају било каквом уређеном, посебном симболизму.“
} 
тричности, а сљедствено и рефлексивном ставу, може да „споји“ игру и надметање.

Агонално априори спонтано се грана на два подједнако изворна, међусобно неодовјива и једносуштаствена облика:на потребуза огледањем са ближим друштвеним окружењем, са другима, чиме се достиже виши степен самоиспуњења. Огледање подразумијева рефлексивни однос којим се узима у обзир оно што је учињено као („огледалски“) одраз себе самога пред собом самим. Но поред рефлексивности и вредновања учињенога, трећи незабилазан момент агоналног априорија јесте у њега усађена потреба за самонадмашивањем као самопотврђивањем због чега се уопште улази у било какво огледање. Изворна форма тога јесте огледање са собом, у настојању да се помјере своје границе и да се себи самоме докаже властита изврсност, или врлина

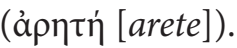

Према њемачком философу спорта Гумберту [Hans-Ulrich Gumbert], основна компонента спорта јесте арете, а не агон (Gumbert, 2005, стр. 46-47). Нама се, међутим, чини да је ствар нешто сложенија, будући да ни предоџбе о арете, нити „аретичке“ праксе нема без самоодношења, тј. без особене агоналности чији је предмет „борба“" против себе, тачније против сопствених, рефлексивно препознатих „слабости“ - тијела и духа. С друге стране, стварност спорта јесте надметање с другима, дакле агон, али крајњи хоризонт тога јесте доказивање властите изврсности - тј. потврђивање и унапређивање своје личне врлине. Дакле, умјесто давања примата једноме или другоме, као што чини њемачки мислилац, савјетније је остати код тога да су арете и агон међусобно неодвојиви, да чак могу дијалектички прелазити једно у друго.

Однос према властитом идентитету подразумијева и посматрање себе као да сам други (односно, обрнуто, као да ме умјесто мене посматра неко други) - тј. с позиције рефлексивне дистанције. Зато је други с којим се надмећем заправо конформан с мојом рефлексивном другошћу с којом посматрам и процјењујем себе и своја достигнућа. Други који покушава да ме надмаши - као и ја њега - јесте виртуални двојник моје рефлексије, пред којим желим да потврдим своју жељу за самонадилажењем. Укратко, други, било који други, као такмац, противник - не и непријатељ, то је акцидентално оличење моје пројекције „бољег“ себе. Гледано из угла спортски несвјеснога, желећи да побиједим њега заправо желим да побиједим себе.

Надметање са другим представља облик (узајамног) племенитог искокришћавања, на начин што ми други, настојећи да ме побиједи, помаже да надиђем себе, односно да изњедрим нешто за шта до тог тренутка нијесам ни знао да сам способан. Такмац је, дакле, „агенс“ (али и „агент“) моје потребе за самонадилажењем, неко ко, према специфичном, хегеловски речено, „лукавству [спортског] ума“, настојећи да ме побиједи - мени помаже да побиједим себе, тј. да из себе извучем (нај)више, више него што бих могао да нема ниједног такмаца. Пошто исто важи у обратном смјеру, тј. за сваког човјек који прихвата своју изложеност сталног стању сталне изазваности, тада треба закључити да, дубински егзистенцијално посматрано, права сврха спорта није побјеђивање другога, већ постојано настојање на самонадилажењу (Simon, 2010).9)

Други, онај с којим се надмећем, улажући свој напор, вјештину и достигнућа, посредно ми показује (иако му то није намјера) докле ја могу, као што важи и обратно. С друге стране, ни тјелесно-духовну властиту врлину није могуће установити искључиво самоодносно jep, на крају крајева, увијек постоји опасност да себе убиједим у било шта што би пријало мојем осјећању самодопадљивости, ма колико то било далеко од истине. Зато је други ту да својим тијелом, напором и страшћу представи и оваплоти непристрасну мјеру у мојем процесу ваздашњег самоодмјеравања. Коначно, сам појам врлине је нешто што је одлика слободног, разумног бивајућег какво може настати само у заједници. У чопору или хорди не може бити никакве врлине, па ни «спортске», везане за физичко огледање. Врлина је такође рефлексивни појам, који се заправо конституише знањем за врлину као врлину. Пореда тога, она урачунава другога и његову другост као особе, као што и у агоналну димензију може да ступи само рефлексивно опосредована особа, а не неко ко би само иживљавало своју животну енергију.

Агоналност је тијесно повезана са жудњом за (симболичком) побједом. То није животињска

\footnotetext{
9) На тај начин, сматрамо, треба читати познату Симонову формулу о спорту као „узајамној потрази за изузетношћу“ (Simon,R., 2010, стр. 203).
} 
одлика, она нема ни представу о побједи - па зато не може ни да „побиједи“, тј. њена фактичка „побједа“ (у борби) за њу никада није побједа, иако „побједничка“ животиња након тога чак може и да се „шепури“, што, међутим, није ништа више до дио инстиктивно заснованог понашања. Када се, примјера ради, два мужјака надмећу за првенство у крду, па један надјача, он тај догађај не може „концептуализовати“ као своју побједу. Човјека, међутим, одликује жудња за побједом као таквом, и то од малих ногу. То је стога што он има однос према ономе што може, и то тако што када чињенично установи шта тренутно може постићи, често одмах добија жељу да узмогне још више од тога, тј. да помакне даље границу својих могућности. Тиме, наравно, опет говоримо о агоналном априорију.

Ту агоналну жудњу нарочито појачава други који се труди да буде што бољи у ономе до чега је и мени стало. И тада спонтана склоност помијерања границе својих могућности бива не само количински појачана него и квалитативно преиначена - у жељу за надмашивањем другога, тј. у жељу за побједом над њиме. Тада се, на први поглед, повлачи у зачеље исходишни порив за помијерањем граница властитих могућности, и у прочеље човјековихтежњидолази жеђ запобједом. Но квалитативни преображај самоодносне жеље за помијерањем властитих могућности у жудњу за побједом над другим показује се као привидан, или, у најбољем случају, дјелимичан - јер се до побједе, како смо рекли, долази само помицањем властитих граница. Побјеђивање (другога), то је заправо напор на постојаном „побјеђивању“ себе самога - собом самим. Само побједник над собом може имати наду да ће „увијек“ бити и побједник над другима. Можда је побједа над другим „слађа“ зато што за њу зна тај други, а често и још понеко (публика као скуп „трећих лица“), али у њеном антрополошком темељу лежи психо-физички механизам самонадилажења, тј. могућност „побједе“ над самим собом, која је не само изворнија него и најтегобнија и најтеже достижна.

Побједе нема без изричитог односа према њој, који је на дјелу и када је ријеч о надметању са собом, и у надметању са другим, као ни без, на трећем мјесту, моје рефлексивне интериоризације односа другога према мени. Захваљујући овом трећем моменту, други престаје бити пуки повод мојега самоогледања, већ постаје противник према којем развијам лични однос супарништва. Но, он може постати моје „огледало“ само зато што ја ту моћ самоогледања већ носим у себи.

„Природну“ агоналност која се испољава и у тежњи за безразложним надилажењем својих тјелесних могућности, назваћемо протоспортским моментом. У питању је наш интерпретативни конструкт којим желимо увести експланаторну схему за освјетљавање априорног услова могућности настанка било какве човјекове надметачке, а на основу тога и спортске дјелатности. Тим протоспортским уводимо један изворно антрополошки, дакле из саме људске „природе“ проистичући, прединституционални комплекс, који је фактичка подлога могућности спортског надметања. Он је директна основа могућности спортског надметања у нелудичким спортовима, док у односу на лудичке такође служи као подлога, али овога пута скупа са играчким поривом. Пошто играчки порив може наћи израза и у неспортским дјелатностима, то ћемо примарно спортским дјелатностима сматрати оне које не укључују никакву игру.

Прототип такмичарске спортске дјелатности, који уједно представља примарну манифестацију протоспортскога̄, које је везивни члан између човјековог бића и било какве спортске радње, јесте трчање. Насупрот њему стоји ходање, као елементарна, за саму животност (људског) организма нужна моторичка форма, путем које се, с обзиром на тјелесну грађу, егземплификује човјекова покретљивост као таква. Примјера ради, код змија та реализација покретљивости налази израза у гмизању, код делфина у пливању итд. Будући да има статус елементарне форме кретања, ходање представља фактичку претпоставку осталих изведених врста кретања, као што су пузање, скакање, пењање, вучење, гурање - насупрот, рецимо, климању [главом], махању [руком] и осталих тјелесних кретњи, јер за њихово извођење није потребно кретање цјелокупног тијела.

Трчање је облик кретања, очигледно, квалитативно различит од ходања. Оно постаје трчање када престане бити брзо ходање - јер ходање и за њега представља стварну претпоставку, не само стога што онај ко не може да хода још мање може да трчи, већ зато што трчање настаје директном квалитативном торичком модификацијом 
ходања, док скакање или пењање представљају, да тако кажемо, елиптичне модификације опште људске способности кретања, која се испољава путем ходања. Иако је ходање базична моторичка форма за све видове кретања која се из њега изводе, трчање заузима посебно мјесто стога што је оно не само директна него и слободна модификација ходања, будући да човјек може да трчи не само када је на то принуђен или када жели да да̂ одушка својој животности - што чине и животиње, већ и када напросто на то ничим није принуђен, осим слободним подстицајем потеклим само из његове воље.

То није цијело објашњење овога питања. Да бисмо га донекле допунили, позваћемо се на једног српског аутора - не научника, већ књижевника: „нагон“ „страст за што бржим кретањем у простор“ потиче од „од моћи афирмација свога голог ја [...] А као круна свега, као сам цвијет на стаблу живота - страст локомоције. “10) Та страст je, дакле, једна од врхунских пројава самога животнога ероса, путем које се, прекомјерним, непотребним изживљавањем, уживачлачки потврђује властита витална укотвљеност у животу сопственом, и Животу уопште.

Да је трчање генеолошки примарна форма човјековог слободног физичког огледања (са окружењем, односно са собом) види се по томе што је човјеку често довољно само то да буде суочен c („отвореним“) простором - па да се некако спонтано осјети „позваним“ да неко произвољно одстојање пређе за што краће вријеме. Тај тихи изазов - који настаје сам од себе „интеракцијом“ човјекове природе и одговарајућег окружења, која га на то „позива“, осјећају већ - чак прије свих - мала дјеца, чим им се стабилизује ход. Њих, наравно, нико на то не мора учити, подстицати. Она ће то већ сама учинити - независно од било каквих процеса учења или социо-културних утицаја. Тај слободни порив се, дакле, већ налази у њима, и зато је он феноменолошки значајан за препознавање изворно самонадметачког момента у човјековом бићу, који смо овдје назвали протоспортскйм. Протоспортско̄ притом још није равно неком конкретном спорту, јер, овај ни у којем својем виду не може бити изједначен са спонтаним поривом за надилажењем и самонадметањем, већ претпоставља планску, институционализовану дјелатност усмјерену ка некој врсти уређеног физичког самоогледања.

\footnotetext{
10) Владан Десница, Прољећа Ивана Галеба, стр. 415.
}

Варијација тог изворног порива за одмјеравање себе са просторним окружењем, јесте изазов даљине - или изазваност даљином, гдје није важно прећи што брже неко одстојање, већ стићи што даље, што више се одмаћи од полазишта, што се онда модификује не само с обзиром на (хоризонталу) даљину, него и (вертикалу) висину (планинарење, падобрански скокови) и дубину (спелеологија, роњење). А на ову спонтану склоност, која се уочава већ код дјеце као нагон експлорације, културноповијесно се надовезује и човјекова потреба да се свијет освијетли, што је у европској култури нашло израза још у старогрчкој просвјећености - не као некаквом посебном историјском „покрету“, већ као стабилној одлици културе. У модерности то је прерасло у просвјетитељски налог да ниједан дио стварности - и спољашње и унутрашње - не смије оставити неосвијетљеним. Стога, модерни успон спорта не коинцидира случајно временски са успоном просвјетитељства.

Протоспорт трчања није нешто из чега произлазесви спортови, чакни свинелудичкиспортови, већ оно што филогентски представља слободну прадјелатност, тј. оно што се врши без потребе за било каквом сврхом изван ње саме. Човјеку страху, потјери или већ из ко зна којег разлога, може потрчати, али то повезује један његов тип покретљивости са озбиљном стварношћу. За нас је важнији могућност слободне десериозације трчања, јер то не показује само још једну додатну црту у човјековом понашању него представља везу сфере „ненужности“ са његовом природом, или макар оним што стоји на мјесту те „природе“. Када човјек први пут - и као врста и као појединац - без икакве спољње присиле потрчи, и то не због пуког осјећаја навирања виталних сила које траже да се испоље, „издувају“ (због чега, рецимо, животиње знају да „непотребно“ потрче), он тиме прескаче праг животне нужности, те виталне „разиграности“, отварајући простор за слободно физичко огледање и надметање са другима.

Када спорт не би имао ову конститутивну црту рационалног усмјеравања физичког напора, која омогућује да испољавање физичке снаге не буде само себи циљ, већ и, под одређеним околностима, средство за постизање неког играчког циља, он би био пуки виталистички феномен, голо ослобађање нагомиланих вишкова биолошке енергије, лишено било каквог (екстравиталног) значења, а камо- 
ли сврхе. Спорт, међутим, започиње тамо гдје је физички напор потчињен неком („спортском“) циљу, гдје, дакле, дух слободно, али опет сходно извјесним, самонаменутим правилима усмјерава тјелесне напоре.

\section{ЛИТЕРАТУРА}

1. Caillois, R. (2001).Man, play and games. University of Illinois Press, Urbana, Chicago.

2. Cassirer, E. (1985). Symbol,Technik, Sprache. Aufsätze aus den Jahren (1927-1933), Meiner, Hamburg.

3. Caysa, V. (2003). Körperutopien. Eine philosophische Anthropologie des Sports, Campus, Frankfurt/M.

4. Caysa, V. (2010).“ÜberempraktischeKonnerscha ft“, Zeitschrift für Kulturphilosophie 1: 65-71.

5. Десница, В. (1982).Прољећа Ивана Галеба. Нолит, Београд.

6. DeGrazia, O. (2008). DerSport "mitanderenAugen". Kritikeinesmodernen Leitbildesnachder Ausdruckstheorie Helmuth Plessners, Berlin(edoc/ hu-berlin.de; приступљено: 1. XII . 2017).

7. Feezell, R. (2013). Sport, Philosophy, andGoodLives. University of Nebraska Press, Lincoln, London.

8. Gumbrecht, H-U. (2005). Lob des Sports. Suhrkamp, Frankfurt/M.
9. Hosta, M. (2014). Etika maksimuma i vrhunski sport. I. Zagorac (ur.), O sportu drugačije. Humanistički aspekti sporta, 199-222. Hrvatsko filozofsko društvo, Zagreb.

10. Копривица, Ч.Д. (2018).Homo maximus. Елементи философије спорта. Укронија, Београд.

11. McKibben, B. (2004). Enough. Staying Human in an Engineered Age. St. Martin's Griffin, New York.

12. Ortega y Gaset, H. (2004). Što je filozofija?, Demetra, Zagreb.

13. Plessner, H. (1974). Sport und Spiel“, Diesseits der Utopie. Ausgewählte Beiträge zur Kultursoziologie. Suhrkamp, Düsseldorf.

14. Simon, R.L. (2010). FairPlay: The Ethics of Sport. Westview Press, Boulder.

15. Sjuts, B. (2019). Skakavac. Igre, život i Utopija. Akademska knjiga, Novi Sad.

16. Sloterdijk, P. (2009). DumußtdeinLeben ändern. Über Anthropotechnik. Suhrkamp, Franfurt/M.

Примљен: 15.11.2019.

Прихваћен: 9.12. 2019.

Online објављен: 13.12.2019. 